\title{
RELEVANSI KURIKULUM SMK KOMPETENSI KEAHLIAN TEKNIK KENDARAAN RINGAN TERHADAP KEBUTUHAN DUNIA INDUSTRI DI KABUPATEN SLEMAN
}

\author{
Dwi Jatmoko \\ Prodi PTK Pascasarjana UNY Yogyakarta \\ jatmoko.uny@gmail.com
}

\begin{abstract}
Abstrak
Penelitian ini bertujuan untuk mengetahui kompetensi yang dikembangkan di SMK Kompetensi Keahlian Teknik Kendaraan Ringan dan relevansinya dengan kebutuhan industri servis mobil. Penelitian ini merupakan penelitian deskriptif. Teknik analisis data yang digunakan yaitu statistik analisis deskriptif. Hasil penelitian (1) relevansi kurikulum SMK Kompetensi Keahlian Teknik Kendaraan Ringan dengan kebutuhan industri servis mobil di Kabupaten Sleman untuk bidang engine sebesar 100\%, chasis 100\%, dan kelistrikan 91,67\%; (2) kompetensi yang dibutuhkan industri servis mobil yang tidak disediakan dalam kurikulum untuk bidang engine sebesar 15\%, chasis 4\%, dan kelistrikan 0\%; (3) kompetensi yang tidak dibutuhkan industri servis mobil namun dilaksanakan dalam kurikulum untuk bidang engine dan chasis 0\%, dan kelistrikan 0,08\%; (4) kompetensi yang dibutuhkan industri servis mobil dan ada dalam kurikulum tapi tidak dilaksanakan di SMK untuk bidang engine sebesar 22,88\%, chasis 14,60\%, dan kelistrikan 12,02\%. Kesimpulan secara umum adalah bahwa kurikulum dalam kategori relevan, namun ada beberapa kompetensi yang tidak terlaksana.
\end{abstract}

Kata kunci: relevansi, kurikulum, dan kompetensi yang dibutuhkan dunia industri.

Dwi Jatmoko

Prodi PTK Pascasarjana UNY Yogyakarta

jatmoko.uny@gmail.com

\begin{abstract}
This research aims to find out a competence which was developed in SMK of light vehicles engineering skill competence and its relevancy by the need of car service industry. This research is a descriptive research. The analysis technique used was descriptive analysis. The result shows that (1) the curriculum relevancy of SMK light vehicles engineering skill competence and the need of car service industry in Sleman in engine field is 100\%, chassis 100\%, and the electricity 91,67\%; (2) the competence needed in car service industry which is not provided in the curriculum in the engine field is 15\%, chassis 4\%, and the electricity 0\%; (3) the competence which is not needed in car service industry but provided in the curriculum, in the engine and chassis field is 0\%, and the electricity 0,08\%; (4) the competence needed in car service industry and is available in the curriculum but is not provided in SMK, in the engine field is $22,88 \%$, chassis $14,60 \%$, and the electricity $12,02 \%$. The general conclusion is that the curriculum is in the relevant category, but some competencies are not developed.
\end{abstract}

Keywords: relevancy, curriculum, and competence needed in industry field. 


\section{PENDAHULUAN}

Salah satu masalah pendidikan kejuruan sekarang adalah bagaimana meningkatkan kesempatan kerja untuk orang-orang muda, yang mempunyai pendidikan menengah kejuruan. Indonesia adalah negara berkembang yang mempunyai populasi anak muda meningkat dengan cepat, dilihat dari data pertumbuhan usia 15-64 (Sumber: Indonesia dalam Angka, http://kompas.com), untuk itu harus dibekali keterampilan kecakapan hidup yang memadai. Di Negara Indonesia, upaya untuk meningkatkan kualitas Sumber Daya Manusia (SDM) telah lama dilakukan dengan berbagai inovasi pada program pendidikan maupun pelatihan. Salah satunya dilakukan melalui Sekolah Menengah Kejuruan (SMK) baik SMK Negeri maupun SMK Swasta. SMK merupakan lembaga pendidikan yang berpotensi untuk mempersiapkan SDM yang dapat terserap oleh dunia kerja, karena materi teori dan praktik yang bersifat aplikatif telah diberikan sejak pertama masuk SMK, dengan harapan lulusan SMK memiliki kompetensi sesuai dengan kebutuhan dunia kerja.

Selama dekade terakhir, sekolah menengah kejuruan di Indonesia telah menjadi sasaran kritik yang substansial bagi kurangnya keterampilan yang memadai dan pengetahuan lulusan yang tidak sesuai dengan kebutuhan industri, dan menjadikan pengusaha tidak puas dengan kualitas lulusan SMK. Sedangkan lulusan mengeluh tentang ketidakmampuan pelatihan sekolah dalam memberikan pendidikan keterampilan, sehingga membuat sulitnya mencari pekerjaan yang memuaskan dalam spesialisasi mereka.

Pada Agustus tahun 2008, Tingkat Pengangguran Terbuka atau TPT masih mendominasi oleh mereka yang berpendidikan setingkat SMA/SMK yaitu jumlah angkatan kerja mencapai 17,26 persen, naik dari Februari 2008 sebesar 14,80 persen. Artinya satu diantara enam lulusan SMK masuk kategori menganggur, diungkapkan oleh Deputi Bidang Statistik Sosial Badan Pusat Statistik, (Arizal Anaf, 2009). Dalam realitas baru ini, sekolah menengah kejuruan menghadapi tantangan untuk terus mengevaluasi program, isi, pelaksanaan, dalam memperbarui kurikulum. Sekolah menengah kejuruan perlu mengintegrasikan materi teori atau praktik kejuruan dengan kompetensi yang ada di industri. Pendidikan kejuruan harus mampu mengajarkan kompetensi yang memenuhi kebutuhan masa depan lulusan dengan melihat realitas tempat kerja dan teknologi yang berkembang. Di Daerah Istimewa Yogyakarta jumlah pengangguran dari tahun ke tahun semakin meningkat. Berdasarkan data Badan Pusat Statistik (BPS) Yogyakarta hasil Survei Angkatan Kerja Nasional (Sakernas) yang dilakukan Februari 2010 diketahui jumlah pengangguran di daerah Yogyakarta meningkat menjadi 3.300 orang dibandingkan tahun 2009 lalu, (Sakernas, 2010).

Banyaknya siswa yang tidak dapat langsung bekerja atau menganggur dimungkinkan disebabkan dari kurang sesuainya kompetensi siswa SMK dengan kebutuhan industri. Hal lain disebabkan banyak dalam pembuatan kurikulum yang dibuat pada tahun sebelumnya dipakai secara terus menerus tanpa konsolidasi dengan DU/DI, dan tanpa mengalami perubahan kurikulum yang disesuaikan dengan kemajuan industri.

Diberitakan juga dari kepala bidang Disnakersos Kabupaten Sleman, bahwa kabupaten paling utara di provinsi DIY yaitu Kabupaten Sleman merupakan daerah yang tercatat mempunyai jumlah pengangguran tertinggi daripada wilayah lain di Daerah Istimewa Yogyakarta dan diperkirakan juga bahwa tahun ini angka pengangguran akan naik lima persen, (Disnakersos, 2009). Di bawah ini juga dapat dilihat data temporer penelusuran siswa SMK di Kabupaten Sleman yang menunjukkan pengganguran relatif belum berubah dari tahun ke tahun (BKK SMK N1 Seyegan).

Semula diharapkan dengan pengembangan SMK tingkat pengangguran akan dapat ditekan, karena pendidikan SMK didasarkan pada kurikulum yang membekali lulusannya dengan keterampilan tertentu untuk mengisi lapangan kerja atau membuka lapangan usaha sendiri. Selain itu, SMK juga dapat diarahkan untuk mengangkat keunggulan lokal sebagai modal daya saing bangsa. Kurikulum SMK sangat memungkinkan untuk dikembangkan sesuai dengan potensi wilayah dan lapangan kerja. Khusus untuk SMK acuan untuk program produktif mengambil dari SKKNI (Standar Kompetensi Kerja Nasional Indonesia). Dengan demikian sekolah se- 
harusnya boleh mengembangkan kurikulum (KTSP) sejauh mengambil SKKNI tersebut. Tetapi dengan adanya ketentuan spektrum SMK dengan standar kompetensi yang harus diambil maka sebenarnya menjadikan ketidak- bebasan sekolah untuk mengambil standar kompetensi apa yang akan diajarkan kepada siswa. Untuk ke depan maka KTSP harus dikembalikan kepada filosofi dan semangat semula tentang otonomi pendidikan.

Tabel 1. Penelusuran Alumni SMK Kabupaten Sleman Tahun 2006-2010

\begin{tabular}{cccccc}
\hline Tahun & SMK & $\begin{array}{c}\text { Jumlah } \\
\text { Siswa }\end{array}$ & Bekerja & Kuliah & $\begin{array}{c}\text { Tidak bekerja/ } \\
\text { Tidak Kuliah }\end{array}$ \\
\hline \multirow{2}{*}{$2006 / 2007$} & Negeri & 1385 & 945 & 127 & 313 \\
& Swasta & 2093 & 1342 & 138 & 613 \\
\multirow{2}{*}{$2007 / 2008$} & Negeri & 1395 & 957 & 166 & 272 \\
& Swasta & 1832 & 1174 & 172 & 486 \\
$2008 / 2009$ & Negeri & 1511 & 1004 & 134 & 373 \\
& Swasta & 2061 & 1123 & 260 & 678 \\
\hline
\end{tabular}

Sumber: BKK SMKN 1 Seyegan

Tabel 2. Kompetensi Keahlian SMK di Kabupaten Sleman

\begin{tabular}{|c|c|c|c|c|c|}
\hline No & SMK & $\begin{array}{l}\text { Jumlah } \\
\text { Rombel }\end{array}$ & No & SMK & $\begin{array}{l}\text { Jumlah } \\
\text { Rombel }\end{array}$ \\
\hline 1. & Administrasi dan Perkantoran & 16 & 17. & Teknik Otomasi Industri & 1 \\
\hline 2. & Akuntansi & 29 & 18. & Geologi Pertambangan & 2 \\
\hline 3. & Pemasaran & 13 & 19. & Teknik Komputer dan Jaringan & 7 \\
\hline 4. & Multimedia & 2 & 20. & Desain dan Produksi Kriya & 7 \\
\hline 5. & Jasa Boga & 6 & 21. & Akomodasi dan Perhotelan & 7 \\
\hline 6. & Busana Butik & 9 & 22. & Agribisnis Ternak Ruminansia & 1 \\
\hline 7. & Teknik Kontruksi Batu dan Beton & 1 & 23. & Teknologi Pengolahan Hasil Pertanian & 1 \\
\hline 8. & Teknik Gambar Bangunan & 4 & 24. & Nautika Kapal Niaga & 1 \\
\hline 9. & Teknik Ototronik & 3 & 25 . & Teknik Kapal Niaga & 1 \\
\hline 10. & Teknik Fabrikasi Logam & 2 & 26. & Busana Butik & 9 \\
\hline 11. & Teknik Kendaraan Ringan & 40 & 27. & Teknik Sepeda Motor & 1 \\
\hline 12. & Kimia Analisis & 1 & 28. & Elektronika Pesawat Udara & 2 \\
\hline 13. & Kimia Industri & 1 & 29. & Air Frame dan Power Plant & 5 \\
\hline 14. & Teknik Permesinan & 4 & 30. & Teknik Pembangkit Tenaga Listrik & 1 \\
\hline 15. & Teknik Perbaikan Bodi Otomotif & 2 & 31. & Teknik Elektronika Industri & 14 \\
\hline 16. & Teknik Audio Video & 2 & 32. & Rekayasa Perangkat Lunak & 1 \\
\hline$\sum$ & 33 Kompetensi Keahlian & & & 196 Rombongan Belajar & \\
\hline
\end{tabular}

Sumber: Surat Keputusan Kepala Dinas Pendidikan Kabupaten Sleman

Pembenahan kurikulum, merupakan salah satu yang harus menjadi fokus dalam rangka perbaikan lulusan SMK. Namun, pembenahan ini harus juga melibatkan semua unsur terkait sehingga hasilnya bisa signifikan. Apalagi mengingat kebijakan pemerintah yang akan terus meningkatkan proporsi pendidikan kejuruan (SMK) ini hingga 70:30 dibandingkan dengan pendidikan menengah
(SMA). Keinginan kuat pemerintah ini harus diimbangi dengan pembenahan kurikulum SMK. Salah satu upaya dalam hal pengembangan SMK adalah melalui pengembangan program keahlian yang relevan dengan kebutuhan industri. Kompetensi keahlian inilah yang menjadi ujung tombak menciptakan link and match SMK dengan dunia kerja. Pada spektrum SMK 2008 terdapat 6 bidang ke- 
ahlian 40 program keahlian yang dibagi lagi menjadi 121 kompetensi keahlian. Direktorat Pembinaan SMK selalu melaksanakan evaluasi dan penataan kembali kompetensi keahlian SMK. Tujuannya adalah untuk meningkatkan relevansi kompetensi keahlian di SMK dengan kebutuhan dunia kerja, baik dalam hal kualitas maupun kuantitas. Kebijakan ini adalah salah satu bentuk nyata dari perencanaan pendidikan kejuruan dengan pendekatan terhadap kebutuhan industri. Di sisi lain keberadaan kompetensi keahlian yang disediakan oleh SMK di Kabupaten Sleman harus proporsional dan sesuai dengan kebutuhan dunia kerja, data kompetensi keahlian SMK di Kabupaten Sleman tersaji seperti pada Tabel 2.

Berdasarkan Tabel 2 terlihat bahwa SMK Kompetensi Keahlian Teknik Kendaraan Ringan ada 40 rombongan belajar dari 18 SMK (2 SMK Negeri dan 16 SMK Swasta), yang berarti rombongan belajar lebih banyak daripada kompetensi keahlian yang lain. Padahal di Kabupaten Sleman jumlah industri manufacture di Sleman dan DIY terbatas, hal ini mungkin terjadi karena meningkatnya kebutuhan masyarakat Kabupaten Sleman terhadap kendaraan. Namun dari keadaan di atas menjadikan peluang kerja di dunia otomotif cukup besar yaitu dalam maintenance atau service kendaraan (munculnya industri service kendaraan).

Keadaan yang ironis, ketika lulusan sudah dididik di sekolah dengan guru yang berkompeten, sudah mempunyai fasilitas baik, dan sudah melaksanakan praktik industri namun pengangguran masih relatif belum berkurang. Dari uraian di atas menunjukkan bahwa barangkali tidak terserapnya lulusan SMK pada dunia industri disebabkan kurang relevannya kurikulum SMK dengan kompetensi yang dibutuhkan di dunia kerja.

\section{Pengertian Kurikulum}

Substansi dari pendidikan kejuruan harus menampilkan karakteristik pendidikan kejuruan yang tercermin dalam aspek-aspek yang erat dengan perencanaan kurikulum, yaitu kurikulum pendidikan kejuruan telah berorientasi pada proses dan hasil atau lulusan. Namun keberhasilan utama kurikulum pendidikan kejuruan tidak hanya diukur dengan keberhasilan pendidikan peserta didik di sekolah saja, tetapi juga dengan hasil prestasi kerja dalam dunia kerja. Finch \& Crunkilton (1999:14) mengemukakan bahwa kurikulum pendidikan kejuruan berorientasi terhadap proses (pengalaman dan aktivitas dalam lingkungan sekolah) dan hasil (pengaruh pengalaman dan aktivitas tersebut pada peserta didik).

Pengembangan program pendidikan kejuruan perlu adanya alasan atau justifikasi yang jelas. Justifikasi untuk program pendidikan kejuruan adalah adanya kebutuhan nyata tenaga kerja di lapangan kerja atau di dunia usaha dan industri. Dasar kebenaran atau justifikasi pendidikan kejuruan menurut Finch \& Crunkilton (1999:15), meluas hingga lingkungan sekolah dan masyarakat. Ketika kurikulum berorientasi pada peserta didik, maka dukungan bagi kurikulum tersebut berasal dari peluang kerja yang tersedia bagi para lulusan.

Kurikulum dalam pendidikan kejuruan tidak terlepas pada pengembangan pengetahuan mengenai suatu bidang tertentu, tetapi harus secara simultan mempersiapkan peserta didik yang produktif. Finch \& Crunkilton (1999:15) mengemukakan bahwa kurikulum pendidikan kejuruan berhubungan langsung dengan membantu siswa untuk mengembangkan suatu tingkat pengetahuan, keahlian, sikap, dan nilai yang luas. Setiap aspek tersebut akhirnya bertambah dalam beberapa kemampuan kerja lulusan.

Sehingga menurut Finch \& Crunkilton (1999:11) kurikulum adalah sejumlah kegiatan dan pengalaman belajar yang harus dilaksanakan peserta didik dalam arahan sekolah untuk mencapai kompetensi tertentu. Konsep kurikulum berkembang sejalan dengan perkembangan teori dan praktik pendidikan yang juga bervariasi sesuai dengan aliran atau teori pendidikan yang dianutnya. Definisi ini ditunjang dengan pendapat Billett, S. (2011:181) mengemukakan bahwa "the curriculum has come to be seen as a document that has been developed in written form and that is used to plan and regulate the experiences to be organised for learners, and for their learning". Kurikulum merupakan sebuah dokumen yang dikembangkan dalam bentuk tertulis dan digunakan untuk merencanakan dan mengatur pengalaman yang terorganisasi bagi siswa dan untuk pembelajaran siswa. Jadi dari pendapat di atas dapat disimpulkan bahwa semua pengalaman 
belajar seorang siswa yang diberikan, di bawah bimbingan sekolah.

Berdasarkan beberapa definisi tentang kurikulum di atas maka dapat disimpulkan, bahwa kurikulum merupakan seperangkat rencana dan pengaturan tentang kompetensi yang dibakukan dan cara pencapaiannya disesuaikan dengan keadaan dan kemampuan masing masing sekolah.

\section{Peran dan Fungsi Kurikulum}

Perubahan sebuah kurikulum sering hanya terfokus pada pengubahan dokumen saja, tetapi pelaksanaan pembelajaran, penciptaan suasana belajar, cara evaluasi atau asesmen pembelajaran, sering tidak berubah. Sehingga dapat dikatakan perubahan kurikulum hanya pada tataran konsep atau mengubah dokumen saja. Ini bisa dilihat dalam sistem pendidikan yang lama dimana kurikulum diletakan sebagai aspek input saja. Dalam dirjen diknas tahun 2008, kurikulum bisa berperan sebagai: (1) kebijakan manajemen pendidikan untuk menentukan arah pendidikannya; (2) filosofi yang akan mewarnai terbentuknya masyarakat dan iklim akademik; (3) pola pembelajaran; (4) atmosfer atau iklim yang terbentuk dari hasil interaksi manajerial sekolah dalam mencapai tujuan pembelajarannya; (5) rujukan kualitas dari proses penjaminan mutu; serta (6) ukuran keberhasilan sekolah dalam menghasilkan lulusan yang bermanfaat bagi masyarakat. Dengan uraian di atas, nampak bahwa kurikulum tidak hanya berarti sebagai suatu dokumen saja, namun mempunyai peran yang kompleks dalam proses pendidikan. Selanjutnya menurut Mc Neil, J.D. (1990:107) isi kurikulum memiliki empat fungsi yaitu:
1. Fungsi Pendidikan Umum
2. Suplementasi
3. Eksplorasi
4. Keahlian

Bagi guru, kurikulum berfungsi sebagai pedoman dalam pelaksanaan proses pembelajaran. Bagi kepala sekolah kurikulum berfungsi untuk menyusun perencanaan dan program sekolah. Bagi pengawas, kurikulum akan berfungsi segai panduan dan melaksanakan supervisi. Sedangkan bagi siswa itu sendiri kurikulum berfungsi sebagai pedoman belajar.

\section{Pengembangan Kurikulum}

Pengembangan kurikulum merupakan sesuatu hal yang dapat terjadi kapan saja sesuai kebutuhan (Oemar Hamalik, 2007:90). Perencanaan kurikulum adalah langkah awal membangun kurikulum ketika pembuat kurikulum mengambil keputusan dan tindakan untuk menghasilkan perencanaan yang akan digunakan oleh guru dan peserta didik. Penerapan kurikulum atau biasa disebut juga implementasi kurikulum berusaha mentransfer perencanaan kurikulum ke dalam tindakan operasional. Evaluasi kurikulum merupakan tahap akhir dari pengembangan kurikulum untuk menentukan seberapa besar hasil-hasil pembelajaran, tingkat ketercapaian programprogram yang telah direncanakan, dan hasilhasil kurikulum itu sendiri.

Prinsip-prinsip yang akan digunakan dalam kegiatan pengembangan kurikulum pada dasarnya merupakan kaidah-kaidah yang akan menjiwai suatu kurikulum. Oleh karena itu, dalam implementasi kurikulum di suatu lembaga pendidikan sangat mungkin terjadi penggunaan prinsip-prinsip yang berbeda dengan kurikulum yang digunakan di lembaga pendidikan lainnya, sehingga akan ditemukan banyak sekali prinsip-prinsip yang digunakan dalam suatu pengembangan kurikulum.

Dalam hal ini, Nana Syaodih Sukmadinata (2009:150) mengetengahkan prinsipprinsip pengembangan kurikulum yang dibagi ke dalam dua kelompok: (1) prinsip-prinsip umum: relevansi, fleksibilitas, kontinuitas, praktis, dan efektivitas; (2) prinsip-prinsip khusus: prinsip berkenaan dengan tujuan pendidikan, prinsip berkenaan dengan pemilihan isi pendidikan, prinsip berkenaan dengan pemilihan proses belajar mengajar, prinsip berkenaan dengan pemilihan media dan alat pelajaran, dan prinsip berkenaan dengan pemilihan kegiatan penilaian.

Pemenuhan prinsip-prinsip di atas itulah yang membedakan antara penerapan satu Kurikulum Tingkat Satuan Pendidikan dengan kurikulum sebelumnya. Karena prinsipprinsip itu boleh dikatakan sebagai ruh atau jiwanya kurikulum. Dalam menyikapi suatu perubahan kurikulum, banyak orang lebih terfokus hanya pada pemenuhan struktur kurikulum sebagai jasad dari kurikulum. Padahal jauh lebih penting adalah perubahan kutural (perilaku) guna memenuhi prinsip- 
prinsip khusus yang terkandung dalam pengembangan kurikulum.

\section{Pendidikan Menengah Kejuruan}

Pengertian lebih spesifik tentang Pendidikan Menengah Kejuruan dijabarkan dalam PP. No. 17 tahun 2010 yang menyatakan bahwa Pendidikan Menengah Kejuruan adalah pendidikan membekali peserta didik dengan kemampuan ilmu pengetahuan dan teknologi serta kecakapan kejuruan para profesi sesuai dengan kebutuhan masyarakat. Definisi tersebut menjelaskan bahwa pendidikan kejuruan adalah pendidikan yang mempersiapkan lulusannya untuk memasuki lapangan kerja. Orientasi semacam ini membawa konsekuensi bahwa pendidikan kejuruan harus selalu dekat dengan dunia kerja. Pendidikan kejuruan dapat dilakukan melalui pendidikan formal ataupun informal. Dalam jalur informal, pendidikan kejuruan dapat dilakukan melalui kursus ataupun balai latihan kerja. Dalam sistem persekolahan di Indonesia, pendidikan kejuruan dilakukan melalui Sekolah Menengah Kejuruan (SMK).

\section{Kurikulum Satuan Tingkat Pendidikan}

Kurikulum Tingkat Satuan Pendidikan (KTSP) merupakan kurikulum yang dikembangkan sesuai dengan satuan pendidikan, potensi sekolah, daerah, karakteristik sekolah atau daerah, sosial budaya masyarakat setempat, karakteristik peserta didik (Mulyasa, 2005:8).

KTSP merupakan pengembangan KBK yang bercirikan:

1. Orientasi pencapaian hasil dan dampak.

2. Berbasis standar kompetensi dan kompetensi dasar yang tertuang

3. pada standar isi.

4. Bertolak dari standar kompetensi lulusan.

5. Memperhatikan pengembangan kurikulum berdiversifikasi.

6. Mengembangkan kompetensi secara utuh dan menyeluruh.

7. Menerapkan prinsip ketuntasan belajar.

Dari uraian di atas dapat ditarik kesimpulan bahwa kurikulum operasional yang disusun dan dilaksanakan oleh masing-masing satuan pendidikan yang merefleksikan pengetahuan, keterampilan, dan sikap sehingga dapat meningkatkan potensi siswa secara utuh.

\section{Kompetensi}

Burke, J. (2005:12) menyatakan bahwa "Competency; statements describe outcomes expected from the performance of professionally related functions, or those knowledges, skills, and attitudes thought to be essential to the performance of those functions". Artinya, kompetensi merupakan pernyataan kemampuan yang menguraikan hasil yang diharapkan dari profesi yang terkait, atau pengetahuan, keterampilan, dan sikap, yang penting dalam pekerjaan tertentu. Dalam hal ini, kompetensi diartikan sebagai pengetahuan, keterampilan, dan kemampuan yang dikuasai oleh seseorang yang telah menjadi bagian dari dirinya, sehingga dapat melakukan perilaku-perilaku kognitif, afektif, dan psikomotorik dengan sebaik-baiknya.

Finch \& Crunkilton (1999:259) mengemukakan "competencies for vocational and technical education are those tasks, skills, attitudes, values, and appreciations that are deemed critical to succes in life and or in earning a living". Artinya kompetensi untuk pendidikan teknologi kejuruan adalah tugas, keterampilan, sikap, nilai-nilai, dan apresiasi yang penting agar berhasil dalam kehidupan dan atau mencari nafkah untuk hidup. Hal tersebut di atas menunjukkan bahwa kompetensi mencangkup tugas, keterampilan, sikap, dan apresiasi yang harus dimiliki oleh siswa agar dapat melaksanakan tugas-tugas yang dipelajarinya di sekolah sesuai dengan kemampuan yang diperlukan oleh dunia kerja.

Berdasarkan beberapa definisi ahli di atas, dapat disimpulkan bahwa kompetensi adalah kemampuan yang dimiliki seseorang yang diperoleh melalui proses pembelajaran dan pengalaman, yakni hasil belajar baik dalam bentuk pengetahuan, keterampilan, perilaku, dan nilai-nilai.

\section{Standar Kompetensi dan Kompetensi Dasar}

Mata pelajaran kejuruan terdiri atas beberapa mata pelajaran yang dikelompokkan dalam Dasar Kompetensi Kejuruan dan Kompetensi Kejuruan, dikembangkan mengacu pada Standar Kompetensi Kerja melalui proses analisis. Jika standar kompetensi mata 
pelajaran kelompok DKK tidak dijumpai pada SKK, maka Standar Kompetensi (SK) dan Kompetensi Dasar (KD) dapat dirumuskan melalui analisis kompetensi kejuruan melalui langkah-langkah:

1. Mendata standar kompetensi yang terdapat pada SKK.

2. Mengidentifikasi kompetensi yang sifatnya mendasar dan melandasi prinsipprinsip keilmuan, dan kompetensi yang menjadi prasyarat untuk kompetensi kejuruan.

3. Mengidentifikasi materi-materi pendukung pada indikator kompetensi kejuruan.

Selanjutnya kompetensi-kompetensi yang tertuang dalam DKK dan KK dikelompokkan dalam standar kompetensi baru yang menjadi nama mata pelajaran sesuai dengan Spektrum Keahlian Pendidikan Menengah Kejuruan berdasarkan Keputusan Dirjen Mandikdasmen nomor 251/C/KEP/MN /2008 tanggal 22 Agustus 2008.

\section{Relevansi Kurikulum}

Kata relevansi berasal dari bahasa Inggris yaitu relevant yang artinya bersangkut paut. Sperber \& Wilson, D. (2009:183), mendefinisikan relevansi dalam dua hal yaitu pertama relevansi merupakan masalah derajat dan kami tidak menyatakan apa pun tentang bagaimana cara menentukan derajat relevansi, kedua relevansi sebagai suatu hubungan antara asumsi dan konteks.

Berangkat dari itu, pengertian kurikulum dalam dunia pendidikan terus mengalami perkembangan sesuai dengan perkembangan zaman sehingga bukan hanya menyangkut sederetan mata pelajaran melainkan menyangkut sebagian besar aktivitas dalam pendidikan. Perkembangan tersebut melahirkan pendapat-pendapat para ahli dalam mendefinisikan kurikulum dari setiap sudut pandang mereka terhadap pendidikan.

Sawyer, D.B. (2004:41) menyatakan "The first is the view of curriculum as a written plan of action, which is reflected incurriculum documents that contain clearly stated learning objectives". Yang artinya kurikulum merupakan rencana tertulis dari kegiatan yang merupakan refleksi dari dokumen kurikulum yang berisi tujuan pembelajaran yang dinyatakan secara jelas.
Melihat kedua definisi di atas maka kurikulum merupakan segala bentuk aktivitas atau kegiatan dalam dunia pendidikan yang dapat mempengaruhi peserta didik selama berada dalam lingkungan sekolah serta hal-hal yang memiliki fungsi untuk mengantarkan pendidikan pada tujuannya. Namun secara khusus kurikulum disini merupakan serentetan rencana pengajaran atau materi yang disusun dalam suatu mata pelajaran tertentu yang tentunya setiap pengadaan dari bahan atau materi pelajaran tersebut menggunakan pertimbangan-pertimbangan matang tentang tujuan pengajarannnya.

Berangkat dari definisi relevansi dan kurikulum, maka relevansi kurikulum adalah keterkaitan atau segala sesuatu yang memiliki hubungan dengan segala bentuk aktivitas atau kegiatan yang ada dalam dunia pendidikan yang dapat mempengaruhi peserta didik serta dapat mewujudkan tujuan pendidikan.

\section{METODE}

Jenis penelitian ini termasuk penelitian deskriptif kuantitatif dengan metode survei. Dalam buku Research Methods in Education by Cohen, L., Manion, L., \& Morrison, K. (2005:169) menyatakan:

Typically, surveys gather data at a particular point in time with the intention of describing the nature of existing conditions, or identifying standards against which existing conditions can be compared, or determining the relationships that exist between specific events.

Metode survei adalah pengumpulan data pada waktu tertentu dengan tujuan menguraikan keadaan yang sebenarnya, atau mengidentifikasi standar yang ada dibanding dengan kondisi yang ada, atau menentukan hubungan antara peristiwa-peristiwa yang spesifik.

Dalam penelitian ini populasi penelitian adalah SMK Negeri atau Swasta yang mempunyai Kompetensi Keahlian Teknik Kendaraan Ringan dan Industri Otomotif yang terjun di bidang service atau maintenance automotive (Agen Tunggal Pemegang Merk) di Kabupaten Sleman Yogyakarta. Teknik pengumpulan data dalam penelitian ini dilakukan dengan menggunakan angket. 
Tabel 3. Kisi-kisi Angket

\begin{tabular}{|c|c|c|c|c|}
\hline No. & Bidang & Standar Kompetensi (SK) & No. Butir (KD) & $\begin{array}{c}\text { Jumlah } \\
\text { (KD) }\end{array}$ \\
\hline \multirow{6}{*}{1.} & \multirow{6}{*}{ Engine } & Menggunakan pelumas/cairan pembersih & 1 & 1 \\
\hline & & $\begin{array}{l}\text { Melakukan overhoul sistem pendingin dan } \\
\text { komponen - komponennya }\end{array}$ & $2,3,4$ & 3 \\
\hline & & Merawat/servis sistem bahan bakar bensin & $5,6,7$ & 3 \\
\hline & & Memperbaiki sistem injeksi bahan bakar diesel & $8,9,10$ & 3 \\
\hline & & $\begin{array}{l}\text { Merawat/servis engine dan komponen- } \\
\text { komponennya }\end{array}$ & $11,12,13,14,15$ & 5 \\
\hline & & Merawat Kendaraan Hitech & 16,17 & 2 \\
\hline \multirow{8}{*}{2.} & \multirow{8}{*}{$\begin{array}{l}\text { Chasis dan } \\
\text { Sistem } \\
\text { Pemindah } \\
\text { Tenaga }\end{array}$} & $\begin{array}{l}\text { Memperbaiki unit kopling dan komponen- } \\
\text { komponen sistem pengoperasian }\end{array}$ & $1,2,3$ & 3 \\
\hline & & Merawat transmisi & 4,5 & 2 \\
\hline & & Merawat unit final drive/gardan & $6,7,8$ & 3 \\
\hline & & Memperbaiki poros penggerak roda & 9,10 & 2 \\
\hline & & Memperbaiki roda dan ban & $11,12,13,14,15,16$ & 6 \\
\hline & & Memperbaiki sistem rem & $17,18,19,20,21$ & 5 \\
\hline & & Memperbaiki sistem kemudi & 22 & 1 \\
\hline & & Memperbaiki sistem suspensi & 23,24 & 2 \\
\hline \multirow{7}{*}{3.} & \multirow{6}{*}{ Kelistrikan } & Merawat baterai & 1,2 & 2 \\
\hline & & $\begin{array}{l}\text { Memperbaiki kerusakan ringan pada rangkaian/ } \\
\text { sistem kelistrikan, pengaman, dan kelengkapan } \\
\text { tambahan }\end{array}$ & $3,4,5,6$ & 4 \\
\hline & & Memperbaiki sistem pengapian & 7,8 & 2 \\
\hline & & Memperbaiki sistem starter dan pengisian & 9,10 & 2 \\
\hline & & Merawat/servis sistem AC (Air Conditioner) & 11 & 1 \\
\hline & & Merawat/servis sistem wiper dan washer & 12 & 1 \\
\hline & & Jumlah KD atau Item & & 53 \\
\hline
\end{tabular}

Sumber : KTSP SMK Kompetensi Teknik Kendaraan Ringan di Kabupaten Sleman

\section{HASIL PENELITIAN}

\section{Data Kompetensi Dasar yang Diajarkan di SMK Kompetensi Keahlian Teknik Kendaraan Ringan}

\section{Bidang Engine}

Bidang engine merupakan sekelompok kompetensi yang menunjang keterampilan dan kemampuan dalam sistem kendaraan, bongkar pasang, perawatan, dan perbaikan mesin ken- daraan. Bidang atau indikator ini terdiri dari enam standar kompetensi (SK) yang disebut sub indikator dan setiap standar kompetensi terdiri dari beberapa kompetensi dasar (KD) yang dalam penelitian ini disebut butir pernyataan penilaian angket. Dari hasil survei penelitian di seluruh atau 17 SMK kompetensi keahlian teknik kendaraan ringan di Kabupaten Sleman untuk bidang engine yang diperoleh hasil sebagai berikut: 
Tabel 4. Kompetensi Bidang Engine yang diajarkan di SMK Kompetensi Keahlian Teknik Kendaraan Ringan di Kabupaten Sleman

\begin{tabular}{clc}
\hline No & Kompetensi Dasar & Frekuensi \\
\hline 1 & Memperbaiki sistem pelumas & 15 \\
2 & Merawat atau servis sistem pendingin & 16 \\
3 & Memperbaiki sistem pendingin & 14 \\
4 & Melakukan overhaul sistem pendingin & 12 \\
5 & Merawat komponen sistem bahan bakar bensin & 17 \\
6 & Memperbaiki komponen sistem bahan bakar bensin & 17 \\
7 & Overhaul sistem bahan bakar bensin & 17 \\
8 & Memperbaiki komponen injeksi bahan bakar diesel & 15 \\
9 & Merawat sistem injeksi bahan bakar diesel & 14 \\
10 & Mengkalibrasi pompa injeksi & 6 \\
11 & Merawat atau servis engine (tune up) & 17 \\
12 & Melaksanaan perawatan/servis komponen engine & 16 \\
13 & Membongkar/ merakit engine serta komponennya & 15 \\
14 & Mengukur dan menguji komponen engine & 16 \\
15 & Memperbaiki dan menyetel komponen engine & 16 \\
16 & Melakukan pemeriksaan pada ECU & 5 \\
17 & Merawat dan memperbaiki sistem injeksi (EFI) & 5 \\
\hline
\end{tabular}

\section{Bidang Chasis}

Tabel 5. Kompetensi Bidang Chasis yang diajarkan di SMK Kompetensi Keahlian Teknik Kendaraan Ringan di Kabupaten Sleman

\begin{tabular}{clc}
\hline No & Kompetensi Dasar & Frekuensi \\
\hline 1 & Merawat atau servis unit kopling & 17 \\
2 & Memperbaiki sistem kopling dan komponennya & 17 \\
3 & Mengoverhaul sistem kopling & 16 \\
4 & Merawat transmisi manual & 17 \\
5 & Merawat transmisi otomatis & 9 \\
6 & Merawat unit final drive penggerak roda depan & 15 \\
7 & Merawat unit final drive penggerak roda belakang & 17 \\
8 & Merawat unit final drive penggerak empat roda & 12 \\
9 & Merawat /servis poros penggerak roda & 15 \\
10 & Memperbaiki poros penggerak roda & 17 \\
11 & Mengganti atau bongkar pasang roda & 17 \\
12 & Memasang ulang ban & 16 \\
13 & Membalans roda dan ban & 10 \\
14 & Melaksanakan pelurusan roda & 13 \\
15 & Melakukan perbaikan Toe In/ Toe Out & 14 \\
16 & Melakukan perbaikan Chamber Caster & 12 \\
17 & Merawat sistem rem & 17 \\
18 & Memperbaiki sistem rem & 17 \\
19 & Melakukan overhaul sistem rem & 17 \\
20 & Memperbaiki/mengganti komponen sistem ABS & 1 \\
21 & Merawat /servis sistem ABS & 1 \\
22 & Memperbaiki berbagai jenis sistem kemudi & 15 \\
23 & Merawat sistem suspensi & 16 \\
24 & Memperbaiki sistem suspensi & 16 \\
\hline
\end{tabular}




\section{Bidang Kelistrikan}

Tabel 6. Kompetensi Bidang Kelistrikan yang diajarkan di SMK Kompetensi Keahlian Teknik Kendaraan Ringan di Kabupaten Sleman

\begin{tabular}{clc}
\hline No & Kompetensi Dasar & Frekuensi \\
\hline 1 & Memperbaiki baterai & 14 \\
2 & Merawat baterai & 17 \\
3 & Memasang sistem pengaman kelistrikan & 17 \\
4 & Memperbaiki sistem pengaman kelistrikan & 16 \\
5 & Merangkai atau memasang sistem penerangan & 17 \\
6 & Memperbaiki sistem penerangan & 17 \\
7 & Memperbaiki sistem pengapian & 17 \\
8 & Merawat/memperbaiki sistem pengapian elektronik & 10 \\
9 & Memperbaiki sistem pengisian & 17 \\
10 & Memperbaiki sistem starter & 17 \\
11 & Merawat /servis sistem AC & 13 \\
12 & Merawat /servis sistem wiper dan washer & 14 \\
\hline
\end{tabular}

Data kompetensi dasar yang dibutuhkan dunia industri otomotif atau ATPM di Kabupaten Sleman dan sekitarnya

Di bawah ini akan ditampilkan deskripsi data kompetensi yang dibutuhkan di ATPM dengan menggunakan angket sebagai gambaran seberapa banyak kompetensi yang dibutuhkan, data ini diambil dari sembilan kepala bengkel ATPM di Kabupaten Sleman.
Dimana terdiri dari tiga bidang, yaitu: Engine, Chasis, dan Kelistrikan.

\section{Bidang Engine}

Data mengenai kebutuhan kompetensi yang dibutuhkan di dunia industri survei penelitian di seluruh ATPM di Kabupaten Sleman dan sekitarnya untuk bidang engine yang diperoleh hasil sebagai berikut:

Tabel 7. Kompetensi Bidang Engine yang dibutuhkan ATPM di Kabupaten Sleman dan sekitarnya

\begin{tabular}{clc}
\hline No & Kompetensi Dasar & Frekuensi \\
\hline 1 & Memperbaiki sistem pelumas & 9 \\
2 & Merawat atau servis sistem pendingin & 9 \\
3 & Memperbaiki sistem pendingin & 9 \\
4 & Melakukan overhaul sistem pendingin & 9 \\
5 & Merawat komponen sistem bahan bakar bensin & 9 \\
6 & Memperbaiki komponen sistem bahan bakar bensin & 9 \\
7 & Overhaul sistem bahan bakar bensin & 9 \\
8 & Memperbaiki komponen injeksi bahan bakar diesel & 7 \\
9 & Merawat sistem injeksi bahan bakar diesel & 8 \\
10 & Mengkalibrasi pompa injeksi & 6 \\
11 & Merawat atau servis engine (engine tune up) & 9 \\
12 & Melaksanaan perawatan/servis komponen engine & 9 \\
13 & Membongkar/ merakit engine serta komponennya & 9 \\
14 & Mengukur dan menguji komponen engine & 9 \\
15 & Memperbaiki dan menyetel komponen engine & 9 \\
16 & Melakukan pemeriksaan pada ECU & 9 \\
17 & Merawat dan memperbaiki sistem injeksi (EFI) & 9 \\
18 & Diagnosis engine electrical & 9 \\
19 & Pemeriksaan emisi gas buang & 9 \\
20 & Memperbaiki injection pump diesel & 6 \\
\hline
\end{tabular}




\section{Bidang Chasis}

Data kebutuhan kompetensi yang dibutuhkan di dunia industri otomotif bidang chasis yang diperoleh berdasarkan metode survei dengan menggunakan angket. Hasil survei penelitian di seluruh Agen Tunggal Pemegang Merk di Kabupaten Sleman dan sekitarnya untuk bidang chasis yang diperoleh hasil sebagai berikut:

Tabel 8. Kompetensi Bidang Chasis yang dibutuhkan ATPM di Kabupaten Sleman dan sekitarnya

\begin{tabular}{lll}
\hline No & Kompetensi Dasar & Frekuensi \\
\hline 1 & Merawat atau servis unit kopling & 9 \\
2 & Memperbaiki sistem kopling & 9 \\
3 & Mengoverhaul sistem kopling & 9 \\
4 & Merawat transmisi manual & 9 \\
5 & Merawat transmisi otomatis & 9 \\
6 & Merawat unit final drive penggerak roda depan & 9 \\
7 & Merawat unit final drive penggerak roda belakang & 8 \\
8 & Merawat unit final drive penggerak empat roda & 9 \\
9 & Merawat /servis poros penggerak roda & 9 \\
10 & Memperbaiki poros penggerak roda & 9 \\
11 & Mengganti atau bongkar pasang roda & 9 \\
12 & Memasang ulang ban & 8 \\
13 & Membalans roda dan ban & 9 \\
14 & Melaksanakan pelurusan roda & 9 \\
15 & Melakukan perbaikan Toe In/ Toe Out & 9 \\
16 & Melakukan perbaikan Chamber Caster & 9 \\
17 & Merawat sistem rem & 9 \\
18 & Memperbaiki sistem rem & 9 \\
19 & Melakukan overhaul sistem rem & 9 \\
20 & Memperbaiki/mengganti komponen sistem ABS & 9 \\
21 & Merawat/servis sistem ABS & 9 \\
22 & Memperbaiki berbagai jenis sistem kemudi & 9 \\
23 & Merawat sistem suspensi & 9 \\
24 & Memperbaiki sistem suspensi & 9 \\
25 & Pemeriksaan air bag & 5 \\
\hline
\end{tabular}

\section{Bidang Kelistrikan}

Tabel 9. Kompetensi Bidang Kelistrikan yang dibutuhkan ATPM di Kabupaten Sleman dan sekitarnya

\begin{tabular}{clc}
\hline No & Kompetensi Dasar & Frekuensi \\
\hline 1 & Memperbaiki baterai & 0 \\
2 & Merawat baterai & 9 \\
3 & Memasang sistem pengaman kelistrikan & 9 \\
4 & Memperbaiki sistem pengaman kelistrikan & 9 \\
5 & Merangkai atau memasang sistem penerangan & 9 \\
6 & Memperbaiki sistem penerangan & 9 \\
7 & Memperbaiki sistem pengapian & 9 \\
8 & Merawat/ memperbaiki sistem pengapian elektronik & 9 \\
9 & Memperbaiki sistem pengisian & 9 \\
10 & Memperbaiki sistem starter & 9 \\
11 & Merawat/ servis sistem AC & 9 \\
12 & Merawat/ servis sistem wiper dan washer & 9 \\
\hline
\end{tabular}




\section{SIMPULAN}

Berdasarkan penelitian yang telah dilakukan dapat diambil kesimpulan mengenai relevansi kompetensi keahlian teknik kendaraan ringan SMK di Kabupaten Sleman, dan keterlaksanaan kurikulum kompetensi keahlian teknik kendaraan ringan SMK di Kabupaten Sleman sebagai berikut:

\section{Relevansi kurikulum SMK Kompetensi Keahlian Teknik Kendaraan Ringan dengan kebutuhan Dunia Industri Service Mobil di Kabupaten Sleman}

Berdasarkan hasil analisis dan pembahasan penelitian ini bahwa relevansi kompetensi keahlian teknik kendaraan ringan SMK di Kabupaten Sleman terhadap dunia industri servis mobil pada 3 bidang kompetensi diperoleh hasil bahwa ketiga bidang kompetensi atau kesemua bidang termasuk kategori relevan, jika dipersentase untuk bidang engine dan chasis 100\%, untuk bidang kelistrikan sebesar 91,67\%. Untuk variabel standar kompetensi, terdapat 20 standar kompetensi yang tercakup dalam ketiga bidang kompetensi tersebut, diperoleh hasil semua standar kompetensi secara general termasuk dalam kategori relevan. Namun setelah diperinci lagi dari 20 standar kompetensi, terdapat dari 52 kompetensi dasar yang termasuk kategori relevan dan 1 kompetensi dasar tidak relevan yaitu memperbaiki baterai pada bidang kelistrikan.

\section{Kompetensi yang dibutuhkan Industri Service Mobil yang tidak disediakan dalam kurikulum di SMK Kompetensi Keahlian Teknik Kendaraan Ringan di Kabupaten Sleman}

Hasil analisis dan pembahasan diperoleh kompetensi yang dibutuhkan Industri Service Mobil yang tidak disediakan dalam kurikulum di SMK Kompetensi Keahlian Teknik Kendaraan Ringan di Kabupaten Sleman pada masing-masing bidang kompetensi sebagai berikut; (1) persentase bidang engine diperoleh sebesar $15 \%$ dalam kategori rendah; (2) persentase bidang chasis diperoleh sebesar 4\% dalam kategori rendah; (3) persentase bidang kelistrikan diperoleh sebesar $0 \%$ dalam kategori rendah.
Kompetensi yang tidak dibutuhkan Industri Service Mobil namun dilaksanakan dalam kurikulum SMK Kompetensi Keahlian Teknik Kendaraan Ringan di Kabupaten Sleman

Hasil analisis dan pembahasan diperoleh kompetensi yang tidak dibutuhkan Industri Service Mobil namun dilaksanakan dalam kurikulum SMK Kompetensi Keahlian Teknik Kendaraan Ringan di Kabupaten Sleman pada masing-masing bidang kompetensi sebagai berikut; (1) persentase bidang engine diperoleh sebesar $0 \%$ dalam kategori rendah; (2) persentase bidang chasis diperoleh sebesar 0\% dalam kategori rendah; (3) persentase bidang kelistrikan diperoleh sebesar $0,08 \%$ dalam kategori rendah.

\section{Kompetensi yang dibutuhkan di Industri Service Mobil dan ada dalam kurikulum tapi tidak dilaksanakan di SMK Kompetensi Keahlian Teknik Kendaraan Ringan Kabupaten Sleman}

Hasil analisis dan pembahasan diperoleh kompetensi yang dibutuhkan di Industri Service Mobil dan ada dalam kurikulum tapi tidak dilaksanakan di SMK Kompetensi Keahlian Teknik Kendaraan Ringan Kabupaten Sleman pada masing-masing bidang kompetensi sebagai berikut; (1) persentase bidang engine diperoleh sebesar 22,88\% dalam kategori rendah; (2) persentase bidang chasis diperoleh sebesar $14,6 \%$ dalam kategori rendah; (3) persentase bidang kelistrikan diperoleh sebesar $12,02 \%$ dalam kategori rendah.

Hasil penelitian ini menunjukkan bahwa relevansi kurikulum SMK kompetensi keahlian teknik kendaraan ringan terhadap kebutuhan dunia industri di Kabupaten Sleman yang meliputi bidang engine, chasis, dan kelistrikan, umumnya sudah termasuk dalam kategori relevan.

\section{DAFTAR PUSTAKA}

Billett, S. (2011). Vocational Education. New York: Springer Science and Business Media.

Burke, J. (2005). Competency Based Education and Training. London: Taylor and Francis e-Library. 
Cohen, L., Manion, L., \& Morrison, K. (2005). Research Methods in Education. London: Taylor \& Francis eLibrary.

Finch, C.R., \& Crunkilton, J.R. (1999). Curriculum Development in Vocational and Technical Education: Planning, Content, and Implementation. Sidney: Allyn and Bacon.

Graduate Institute of International and Development Studies. (September 2005). Network for Policy Research,
Review and Advice on Education and Training, p. 29 - 31. Diambil tanggal 8 Januari 2013, dari http://www.norrag. org/de/publications/norrag-news

Mc Neil, J.D. (1990). Curriculum a comprehensive introduction. London: Library of congress cataloging in publicating data.

Sawyer, D.B. (2004). Fundamental Aspects of Intreperter Education. Amsterdam: Benjamins Publishing Company. 